\title{
Proceeding
}

9th INSHS International Christmas Sport Scientific Conference, 4-6 December 2014. International Network of Sport and Health

Science. Szombathely, Hungary

\section{Monitoring of hemodynamic changes depending on the physical load - case study}

\author{
JANA MILOVA \\ Department of Physical Education and Sport, Faculty of Education, University of Hradec Kralove, Czech Republic
}

\begin{abstract}
Milova, J. (2015). Monitoring of hemodynamic changes depending on the physical load - case study. J. Hum. Sport Exerc., 9(Proc1), pp.S293-S301. The paper presents partial results of the research: Changes of Hemodynamics Indicated through Noninvasive Laboratory Method of Recording of Cardiovascular System in Dependence on Physical Strain during Studies of Students of Physical Education. We describe the possibilities of using this method to determine the effect of physical loading on the body. The method uses measurements of forces and moments resulting from cardiac activity using force platforms to measure the time from the moment of opening of the aortic valve to the shock pulse wave on abdominal bifurcation. We are building on previous research of this issue (Šeba \& Křiž, 2008). In the initial hypothesis, we assume that changes in pulse wave velocity are analogous to the changes in the level of motoric performance indicated by an endurance motoric ergometry test and examination. Participants, who improve the level of fitness, also improve the pulse wave velocity and vice versa. For the examination of pulse wave velocity we chose the principle of balistokardiografie. The method for detecting physical fitness was an endurance motoric test. Physical loading took place over two semesters with increased frequency of weekly physical activities according to the curriculum of the field of physical education. Results: In this case study we describe four individuals, two men and two women with different levels of physical fitness. For the men and for the woman with lower baseline levels of physical fitness substantive improvements have been made in both variables (motoric tests and pulse wave) and on the contrary the man and the woman with higher initial levels of physical fitness have not improved in the monitored variables. Conclusion: The present case study in qualitative research indicated the possibility of application of this approach in our future work, when we increase the number of participants and repeat the experiment. This allows us to refine the work using the quantitative data analysis. Key words: NON-INVASIVE TESTING, BALLISTOCARDIOGRAPHY, PULSE WAVE VELOCITY, STUDENTS OF PHYSICAL EDUCATION.
\end{abstract}

Corresponding author. Department of Physical Education and Sport, Faculty of Education, University of Hradec Kralove, Rokitanskeho 62, Hradec Kralove 3, 500 03, Czech Republic

E-mail: jana.milova@uhk.cz

9th INSHS International Christmas Sport Scientific Conference, 4-6 December 2014. International Network of Sport and

Health Science. Szombathely, Hungary.

JOURNAL OF HUMAN SPORT \& EXERCISE ISSN 1988-5202

(c) Faculty of Education. University of Alicante

doi:10.14198/jhse.2015.10.Proc1.17

VOLUME 10 | Proc1 | 2015 | S293 


\section{INTRODUCTION}

In this research we monitor the hemodynamic changes influenced by physical load during students' of physical education and sports study. Monitoring of hemodynamic changes is mainly used in medicine (clinical practice) for diagnostic assessment of the cardiovascular system of patients, mostly when providing primary and secondary prevention of cardiovascular (hemodynamic) abnormalities (Bláha, 2006).

Hemodynamic is defined as the blood circulation on basis of human organism's physical principles. It deals with the blood flow in circulatory system, blood pressure in different parts of human body under different conditions, activity of a heart as a pump, blood vessels as tubes transporting blood etc. (Vokurka \& Hugo, 2009). The main parameters are blood pressure, heart rate, cardiac output, oxygen saturation pf blood, peripheral vascular resistance (Hadian \& Pinsky, 2007; Bláha, 2006). The movement of blood in veins is a consequence of the heart activity. The blood that is forced out of the heart to aorta during systole causes a pressure-pulse wave that spreads to the periphery through the walls of veins and opens the veins as it moves, and that can be identified by touch as a pulse (Trojan, 1999). The movement of the pulse wave is another important hemodynamic indicator of conditions of cardiovascular system (Safar et al., 2002, Kříž \& Šeba 2008).

Invasive and non-invasive examinations are used to diagnose hemodynamic parameters. Invasive monitoring, which involves a violation of a skin cover, contact with body fluids of the examined person, can be done surgically or with catheters (sensors), e.g. Seldinger technique (Černý, 2000). Non-invasive techniques, which do not involve a violation of a skin cover, us: electrocardiography, echocardiography, Doppler colour ultrasonography, computed tomography, nuclear magnetic resonance, electrical bioimpedance, ballistocardiography (Barčiaková et al., 2011; Black, 2000; Štejfa, 1998).

For our research we used non-invasive method of balistocardiography principle, which is based on the recoding of minor body movements. Use of these movements to obtain information about heart activity is a method that has been known for over 70 years (Barčiaková et al., 2011). The core of balistocardiography is Newton's third law, i.e. action - reaction law. During the cardio cycle contractions of a heart muscle appear and they cause fierce blood movement. Blood is forced out of a left ventricle to aorta during systole. The resulting pressure wave spreads through the bloodstream. It changes its direction (e.g. in the aortic arch) and is partially rebounded at sites of ramification of large arteries (i.e. aorta bifurcation, pelvic divination of artery to inner and outer pelvic artery). These events are associated with the transfer of the movement between a heart and blood and between arteries and the pressure wave. In accordance with the action reaction principle, the change of the movement of a certain volume of blood as a result of a contact with a heart (artery) wall is showed as a movement of the wall itself, i.e. the whole object (a heart, a certain part of an artery) tha participated in the transfer. This movement is reflected by slight body movements which can be scanned with sufficiently sensitive equipment. After multiple enlargement of the recorded signal we obtain a curve - ballistocadiogram (Barčiaková et al., 2011; McKay, W. et al., 1999).

In this paper we demonstrate the use of a method based on differential geometry of curves to analyse data obtained by ballistocardiographic measuring (Křiž \& Šeba, 2008). We used a technique of measurement of the forces and their moments resulted from a heart activity using force platform - a device measuring force components and moments of its effect on a certain desk. In the past, several studies have demonstrated the ability of a force platform to detect heart activity (Pagnacco, 1999). Using this technique researches have been done, during which the results of the measurement of time differences of the pulse waves in rebounding from the aortic arch to the abdominal aortic bifurcation, measured invasively with catheters and 
non-invasively with ballistocardiographic method. Kř́ž \& Šeba (2008) states, that correlation among those measurements has been found, so the signals are precisely in moments of expected arrival of the pulse wave into aortic arch and abdominal bifurcation. However, we cannot talk about a pulse wave velocity. This would depend primarily on the length between the aortic valve and the abdominal bifurcation, which individually differs with each participant. Because of that only sort of time differences are available - from the opening of the aortic valve to the collision of the pulse wave into abdominal bifurcation in (ms) (Figure 1 ), which, however, ale always measured on the same participant.

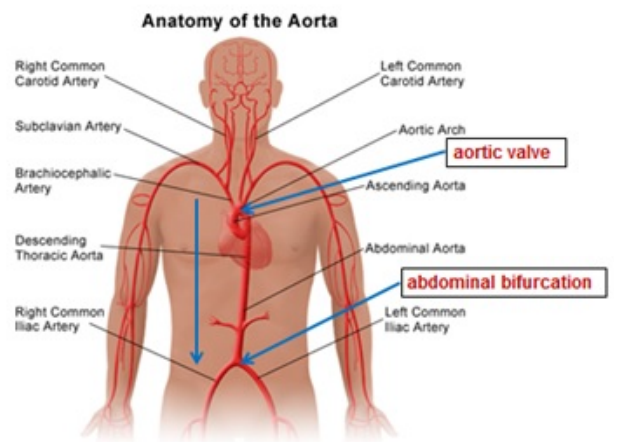

Figure 1. Anatomy of the Aorta (according to http://www.muschealth.com/aorta/your_aorta)

Hemodynamic parameters are influenced by many factors. The endogenous factors: health condition, psyche, neuro humoral regulation, vegetative nerve function, genetics, age. Among the exogenous influencing hemodynamic are: time - biorhythms, food intake, alcohol, caffeine, smoking, drugs, O2 partial pressure, physical load (Vokrouhlický \& Kvasnička, 1986).

Due to long-term physical loading, mostly of aerobic character, adaptation changes of cardiovascular system and therefore changes of hemodynamic parameters occur (Havličková, 1999). The adaptation is based on the need to deliver oxygen and metabolic substrates faster to the muscles, where the actual energy expenditure takes place (Radvanský, 2011). The adaptive changes are shown by e.g. resting and maximum heart rate decrease, higher contractility and ejection fraction of a heart, lower rise of a blood pressure during exercise (Cinglová, 2010) and also by increase of arterial elasticity, which causes partial absorption of the initial pulse wave velocity - i.e. the wave velocity decreases (Bertovic et al., 1999; Trojan, 1999). This fact is a key object of our research.

Laboratory stress tests are used to diagnose the fitness level, the state of cardiovascular system and adaptation to the load. The advantages of laboratory tests are standard conditions and possibility to repeat and compare (Cinglová, 2010). The sources of physical load are e.g. ergometers (bicycle, treadmill). The monitored components of aerobic fitness are e.g. maximal aerobic power $\left(\mathrm{VO}_{2} \mathrm{max} / \mathrm{kg}\right)$, aerobic endurance (to endure in aerobic performance on a certain $\% \mathrm{VO}_{2} \mathrm{max}$ ). The level of adaptation of cardiovascular system to endurance performance is indirectly shown in W170 test (Novotný, 2003).

The level of a physical fitness of aerobic character can be also diagnosed by field motor tests: Cooper test, Burpee test, complete motor test - Jacík, graded 20 metres shuttle run - Leger test (Zvonař et al., 2011). These tests are evaluated according to standardized rules in operation. The use then tends to head for area of recreational and performance sportsmen than for area of professional sport.

The level of adaptive changes of an organism depends on the kind, intensity and duration of the physical load (Vokrouhlický \& Kvasnička, 1986). The loading of students studying at the faculty of pedagogy with 
specialization in physical education differs. In the first year of studies students take courses that include development of all movement abilities (strength, speed, stamina, flexibility, agility). Those include: athletics, swimming, basketball, volleyball, motion games, basic gymnastic and also various courses of skiing, cycling, orienteering. The duration of loading is for two semesters, including courses in exam period. The intensity of loading appears to differ among students. The study program increased frequency and intensity of physical activity for students, who are not and were not active sportsmen. For active students the program either increased the physical activity or replaced the existing. Due to the duration and content of the subject, the development of endurance and agility prevails.

In addition to gained theoretical knowledge, in our research we seek the answer for this question: Is the change of pulse wave velocity a valid indicator of a change in the level of physical fitness?

\section{MATERIAL AND METHODS}

The aim of this paper is to track changes in the pulse wave velocity depending on the physical load of physical education students and to determine whether these changes will be similar to changes in levels of fitness.

Following hypothesis of this paper has been stated: We assume that changes in the pulse wave velocity are analogous to the changes in the level of motoric performance indicated by an endurance motoric test and an ergometric examination. The participants, who improve the fitness level, also improve the pulse wave velocity, and vice versa.

Analysis

The methodological approach is empirical and causal, the research plan is the quasi - experiment with qualitative and quantitative analysis of four casuistic of divergent groups.

\section{Participants}

Students of the first year (men, women aged 20-21) of the physical education studies at the pedagogical faculty of the University of Hradec Králové.

Deliberate choice:

- $\quad$ students with low level of physical fitness (1 man, 1 woman)

- $\quad$ students with high level of physical fitness (1 man, 1 woman)

The criterion for division into two divergent groups was based on the input laboratory and motoric tests.

Description of the research plan

The research took one academic year and had 3 stages.

\section{Pre-test (October)}

- $\quad$ at the beginning of their studies the students undergo an ergonomic examination in the office of physical education doctor - this examination provides important factors expressing the physical fitness level $\left(\mathrm{VO}_{2}\right.$ max, W170/kg, etc.)

- $\quad$ at the same time they undergo standard endurance motoric test (Léger shuttle run) according to the standardized published rules (Kovář \& Měkota, 2002)

- $\quad$ to examine the pulse wave velocity we chose ballistocardiographic principle - a non-invasive method using a force platform mentioned above. 
2. Period of the actual physical loading (November - May)

- $\quad$ took part over two semesters with increased weekly frequency of movement activities according to the physical education curriculum

\section{Post-test (June)}

- $\quad$ a standard endurance motoric test (Léger shuttle run)

- $\quad$ a non-ivasive testing of the pulse wave velocity - a method using a testing bed with a force platform of a platform

\section{Methods and techniques of data collecting}

\section{Laboratory testing of the pulse wave}

To explore the pulse wave velocity we chose a measurement on the basis of ballistocardiography.

When examined, the participant lie down on a special testing bed with a force platform (Figure 2) which is equipped with for sensors. Each of the sensors measures signals in three perpendicular planes $(x, y, z)$ (Figure 3). As a result we gain 12 digital signals (Pagnacco et al., 1999). Under these circumstances, by signal we mean any movement of a heart or its parts in the given levels a movement of blood in arteries (a pulse wave). The sensors are so sensitive that they can monitor even minor vibrations which are a manifestation of the blood ejection from the ventricles during a systole. Also a ballistocardiografic sensor with applied EKG (elektrokardiograf) electrodes is put onto a sternum of a participant. All forces and moments of forces acting during each cardiac contraction are recorded during the measurement. The set of these forces is the ballistocardiogram mentioned above. The result of the examination is then a record of a ballistocardiogram EKG measured at the same moment. It is the synchronization of ballistocardiogram and EKG that is the essence of filtering all unwanted movements and vibrations. A great advantage of this method is its speed. The measurement took four minutes. In comparison with other comparable methods, e.g. the echocardiography, ballistocardiography is also much cheaper (Barčiaková et al., 2011; Křiž \& Šeba 2008; Studnička 2012). The details of evaluations using a special software monitoring heart activity and hemodynamics parameters are described by Křiž \& Šeba (2008).

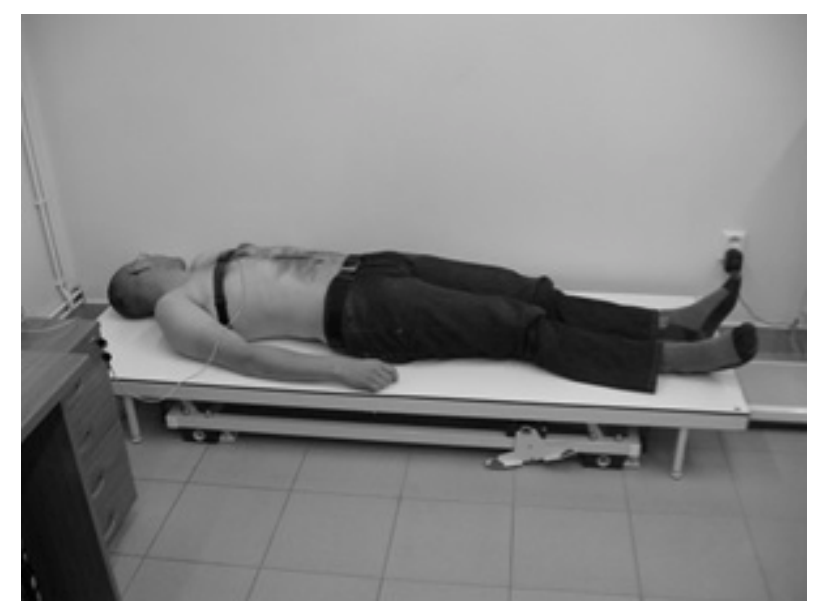

Figure 2. A participant on a table bed with a force platform (Studnička, 2013) 
The process of the test - measurement time 4 minutes

- $\quad$ measurement of the size of the forces in the basic planes $x, y, z$

- $\quad$ monitoring of EKG

- $\quad$ pressure measurement

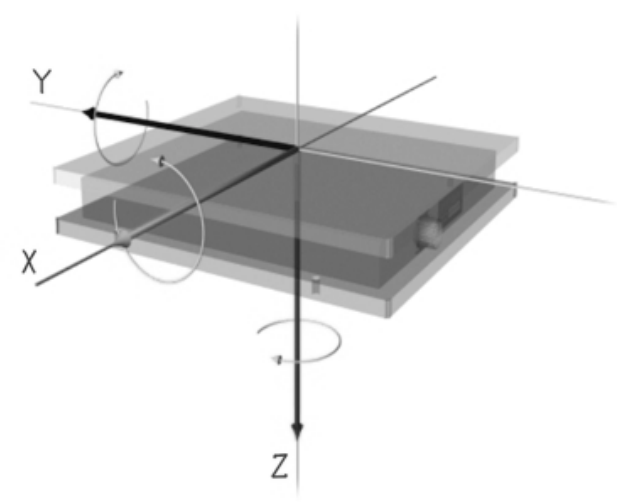

Figure 3. Measurement of the size of the forces in planes $x, y, z$ (Kř́žz \& Šeba, 2008)

2. Motoric testing

Methods chosen for the assessment of the fitness level:

a) Endurance motoric test - a graded shuttle run of 20 metres length - Leger test applied according to Kovář \& Měkota (1996). Phase evaluation has been modified and refined for a specific number of individual 20 metres sweeps.

b) An entrance loading laboratory test determining a W170/kg value.

A W170 test is a determination of the performance that the participant is able to make at the heart rate of $170 /$ minute (on a bicycle ergometer) (W); it is suitable to convert the performance to weight in $\mathrm{kg}(\mathrm{W} / \mathrm{kg})$ for inter-individual evaluation; the values indirectly indicate the level of adaptation of mostly cardiovascular system to endurance performance (Novotný, 2013).

The physical loading took place over two semesters with an increased weekly frequency of movement activities according to the physical education curriculum.

\section{RESULTS}

In this case study we describe four people, two men and two women, with different fitness levels.

With both the man and the woman with lower initial fitness level an improvement has been made in both variables (motoric test and pulse wave) and on the contrary with both the man and the woman with higher initial fitness level have made no improvement in any of the two monitored variables (Table 1). 
Table 1. The results of differences between physical load hemodynamic and pulse wave

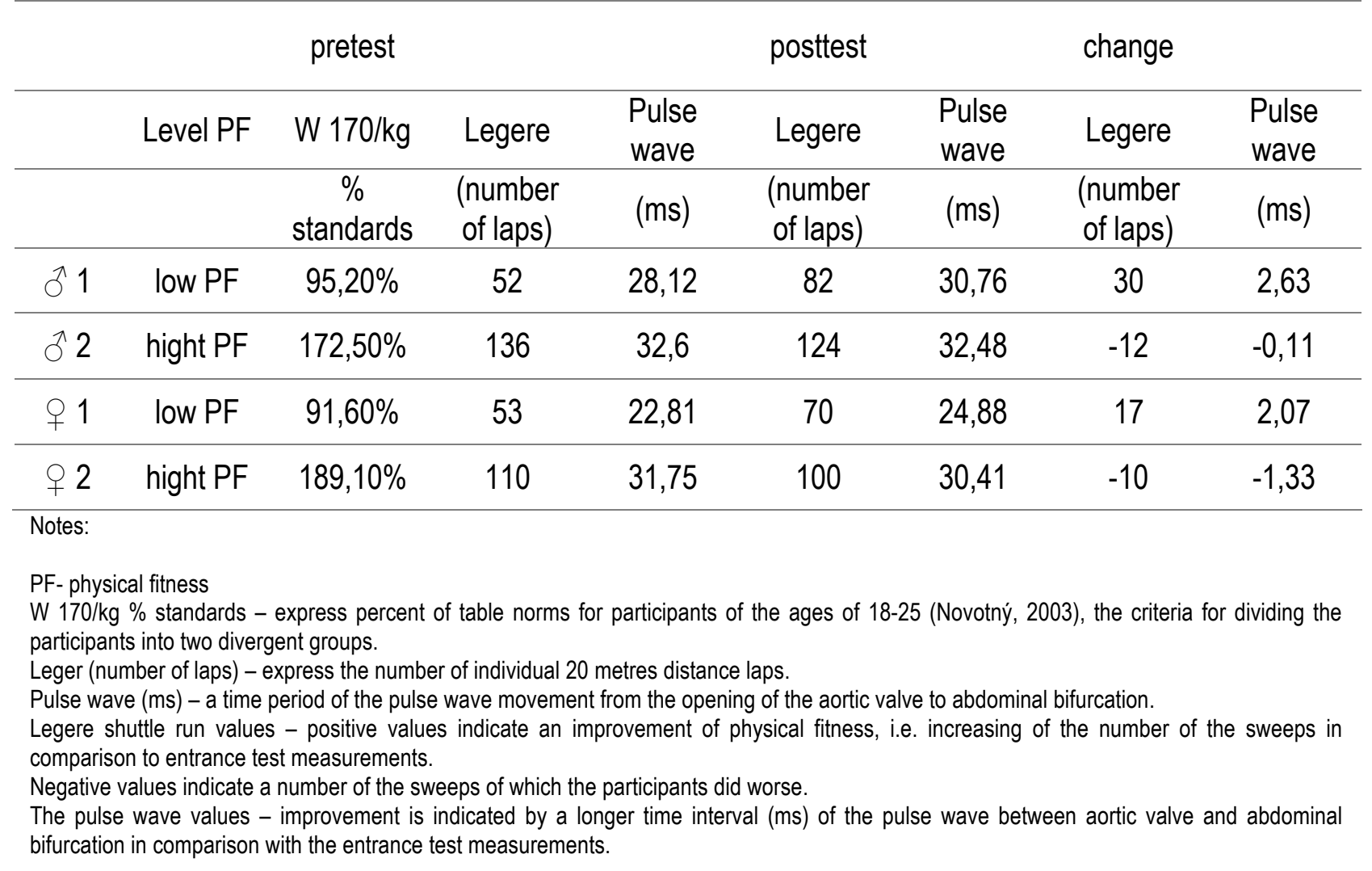

\section{DISCUSSION}

A lot of authors deal with the impact of physical loading on human organism, e.g. Novotný (2003); Cinglová (2011); Bertovič (1999). This research is based on monitoring of hemodynamic, specifically on the pulse wave velocity as one of possible indicators of adaptation to physical load. As confirmed e.g. by Máček \& Radvanský (2011), Trojan (1999), Bertovič (1999), Safar et al. (2002), especially long-term aerobic load has an effect of arterial elasticity improvement and this improvement leads to partial absorption of pulse wave velocity.

Based on the research of Křiž \& Šeba (2008) we chose a non-invasive method on ballistocardiography principle using force platform able monitor minor movements resulting from cardio activity with sufficient precision. The ability to monitor the pulse wave by this platform is confirmed also by Studnička (2013); Barčiaková et al. (2011). Its advantages are low cost, speed, and especially non-invasive and gentle way for the examined person (Kř́ž \& Šeba, 2008).

Another method chosen to monitor the adaptation of human organism to physical load is endurance motoric test - a graded endurance shuttle run for 20m - Legr test, by which, according to Kovář \& Měkota (1996), it is possible to evaluate physical fitness. After two semesters of loading, the performance in Leger test should naturally be higher. That was confirmed by this research in case of male and female participants, who had had low level of physical fitness at the pre-test. The Leger test, although perfectly interpreted with results apparent immediately, largely depends on the motivation of a participant. Adequate motivation of participants may affect the testing results. Whether this can be arranged or if it is possible to use a different motoric test is a question for further research. Using of laboratory test in post-test as well would surely 
ensure more objective results, because this method can determine the state of cardio system very accurately (Novotný, 2003).

Intensity and duration of physical load have also an important influence on the change of hemodynamic. Mainly aerobic loading more than three times per week during one year is sufficient according to Máčka \& Radvanský (2011), but the exact intensity of the load was not registered. It would be appropriate to add for the objectivity of further research.

In this case study, the change of physical fitness (after long-term physical loading) was monitored through the motoric and laboratory test. With both man and women with the lower level of physical fitness at the entrance test, an analogue change (improvement) was achieved at both tests. With both man and women with the higher level of physical fitness at the entrance test, there was no change at any of the tests. An analogy among tests has been proved and the hypothesis was proved by that.

We did not find a match for comparison of the used method to other studies, because the authors of published studies have approached a similar problematics with different methods.

Whether it would be possible to use this non-invasive method for monitoring the response of organism to loading will not be shown until further extensive research. Interpreted results are indicative and can be used as initial information.

\section{CONCLUSIONS}

In this case study we describe four participants, two men and two women with different fitness level, in the framework of qualitative research. The aim of this study was to monitor changes in the pulse wave velocity depending on the physical load of physical education students and to find out if those changes are analogical with the changes of physical fitness level.

With both the man and the woman with lower initial fitness level an improvement has been made in both variables (motoric test and pulse wave) and on the contrary with both the man and the woman with higher initial fitness level have made no improvement in any of the two monitored variables. The hypothesis of this relationship has been proved in ways of indication in the framework of this case study; the aim of this paper was achieved.

Recommendation for further work lies in a significant increase of the monitored set, in more accurate characterization of experimental intervention of the physical load. The case study suggested the possibility of using this methodology in further work with possibility to precise the results by quantitative analysis of data.

\section{REFERENCES}

1. Barčiaková, L., Pirk, J., Šeba, P. \& Křǐž, J. (2011). Vývoj balistokardiografie od roku 1877. Cor Vasa, 53, pp.72-74

2. Bertovic D., et al. (1999). Muscular strength training is associated with low arterial compliance and high pulse pressure. Hypertension, 33, pp.1385-1391. 
3. Bláha, J. (2006). Monitorace hemodynamiky. Multimediální podpora výuky klinických a zdravotnických oborů: Portál 1. lékařské fakulty Karlovy Univerzity v Praze. Retrieved 9. 10. 2014 from the World Wide Web: http://portal.If1.cuni.cz/clanek-652-monitorace-hemodynamiky.

4. Cinglová, L. (2010) Vybrané kapitoly z tělovýchovného lékařství. Praha: Karolinum.

5. Černý, V. (2000). Invazivní hemodynamické monitorování v praxi. Praha: Grada.

6. Havlíčková, L. (1999). Fyziologie tělesné zátěže l: obecná část. Praha: Karolinum.

7. Kovár̆, R., \& Měkota, K. (1996). Unifittest (6-60): manuál pro hodnocení základní motorické výkonnosti a vybraných charakteristik tělesné stavby mládeže a dospělých v České republice. Ostrava: Pedagogická fakulta Ostravské univerzity.

8. Kř́žz, J. \& Šeba, P. (2008). Force plate monitoring of human hemodynamics. Nonlinear

Biomedical Physics; 2:1. Retrieved 19. 10. 2011 from the World Wide Web: http://www.nonlinearbiomedphys.com/content/2/1/1

9. Kříž, J., \& Šeba, P. (2008) Mechanical monitoring of human cardiovaskular system. In: Analysis of biomedical signals images, proceeding of proceeding of 19th international conference Biosignal, Brno.

10. Máček, M., \& Radvanský, J. (2011). Fyziologie a klinické aspekty pohybové aktivity. Praha: Galén.

11. McKay, W., Gregson, P., McKay, B., \& Militzer, J. (1999). Sternal acceleration ballistocardiography and arterial pressure wave analysis to determine stroke volume. Clin Invest Med, 22(1), pp.4-14.

12. Mehrnaz, H., \& Pinsky, M. (2007). Funkční monitorování hemodynamiky. Current Opinion in Critical Care; 1, pp.66-71. Retrieved 7. 11. 2014 from the World Wide Web: http://www.csarim.cz/Public/csarim/doc/casopisy/2007/COCC_3_07.pdf

13. Měkota, K., \& Blahuš, P. (1983). Motorické testy v tělesné vychově. Praha: SPN.

14. Novotný, J. Kapitoly sportovní mediciny. (2003) Retrieved 20.1. 2012 from the World Wide Web: http://is.muni.cz/do/fsps/e-learning/kapitolysportmed/index.htm

15. Pagnacco, G. Oggero E, O'Reilly P.F, Warnecke J.M, \& Berme N. (1999). Design and testing of a 6-component ballistocardiographic bed. Biomedical Sciences Instrumentation: 35, pp.57-62.

16. Safar, M. E., Henry, O., \& Meaume, S. (2002). Aortic Pulse Wave Velocity: An Independent Marker of Cardiovascular Risk. Am J Geriatr Cardiol, 11(5), pp 295-298, 304.

17. Studnička, F. (2013). Analýza biomedicínských signálú získaných pomocí balistokardiografických měření. Disertační práce. Univerzita Hradec Králové, Pedagogická fakulta, Hradec Králové.

18. Studnička F., Šeba P., Jezbera D., \& Křiž J (2012). Continuous monitoring of heart rate using accelerometric sensors, 35th International Conference on Telecommunicati-ons and Signal Processing (TSP) \{ conference proceedings, pp.559-561.

19. Štejfa, M. Kardiologie. (1998) 2. přepracované a doplněné vydání. Praha: Grada

20. Trefný, Z. (2003). New Trends in Balistocardiography. Measurement science. Review, 3, pp. 45-48.

21. Trojan, S. (1999). Lékařská fyziologie Praha: Grada Publishing.

22. Vokrouhlický, L, Kvasnička, J. (1986). Klinická fyziologie oběhového systému. Praha: Státní pedagogické nakladatelství.

23. Vokurka, M., \& Hugo, J. (2009). Velký lékařský slovník, 9. vydání. Maxdorf. pp.1160.

24. Zvonař, M., Duvač, I., Sebera, M., Kolářová, K., Vespalec, T., \& Maleček, J. (2011). Antropomotorika pro magisterský program tělesná výchova a sport.1. vydání. Brno: muni PRESS. 